\title{
Diagnostic Value of Serum Level of Soluble Tumor Necrosis Factor Receptor II $\alpha$ in Egyptian Patients With Chronic Hepatitis C Virus Infection and Hepatocellular Carcinoma
}

\author{
Shawky A Fouad ${ }^{1, *}$; Nehal H Elsaaid ${ }^{1}$; Nagwa A Mohamed ${ }^{2}$; Osama M Abutaleb ${ }^{1}$ \\ ${ }^{1}$ Department of Internal Medicine, Faculty of Medicine, Cairo University, Cairo, Egypt \\ ${ }^{2}$ Department of Clinical and Chemical Pathology, National Research Center, Cairo, Egypt \\ ${ }^{*}$ Corresponding Author: Shawky A Fouad, Department of Internal Medicine, Faculty of Medicine, Cairo University, P. O. Box: 12553, Cairo, Egypt. Tel/Fax: +20-35822980,, E-mail: shawky- \\ abdelhamid@gmail.com
}

Recieved: September 1, 2014 Accepted: September 11, 2014

\begin{abstract}
Background: The prognosis of hepatocellular carcinoma (HCC) is unfavorable and needs serum markers that could detect it early to start therapy at a potentially curable phase.

Objectives: The aim of this study was to determine the value of serum soluble tumor necrosis factor (TNF) receptor-II $\alpha$ (sTNFR-II $\alpha$ ) in diagnosis of HCC in patients with chronic hepatitis C virus (HCV) infection.

Patients and Methods: The study was performed on 110 subjects who were classified into five groups. Group I included 20 patients with chronic noncirrhotic HCV infection and persistently normal transaminases for $\geq 6$ months. Group II included 20 patients with chronic noncirrhotic HCV infection and elevated transaminases. Group III included 20 patients with Chronic HCV infection and liver cirrhosis. Group IV included 20 patients with chronic HCV infection with liver cirrhosis and HCC. Group V included 30 healthy age and sex-matched controls. Medical history was taken from all participants and they underwent clinical examination and abdominal ultrasonography. in addition, the following laboratory tests were requested: liver function tests, complete blood count, HBsAg, anti-HCVAb, HCV-RNA by qualitative PCR, and serum levels of $\alpha$-fetoprotein (AFP) and sTNFR-II $\alpha$.

Results: The serum level of sTNFR-II $\alpha$ was significantly higher in patients with HCC in comparison to the other groups. A positive correlation was found between the serum levels of sTNFR-II $\alpha$ and AST and ALT in patients of group-II. Diagnosis of HCC among patients with HCV infection and cirrhosis could be ascertained when sTNFR-II is assessed at a cutoff value of $\geq 250 \mathrm{pg} / \mathrm{mL}$.

Conclusions: Serum sTNFR-II $\alpha$ could be used as a potential serum marker in diagnosing HCC among patients with HCV infection.
\end{abstract}

Keywords: Liver Cirrhosis; Hepatocellular Carcinoma; Hepatitis C Virus; s TNF-RII

\section{Background}

Millions of people are affected with hepatitis C virus (HCV) infection worldwide that proceeds to cirrhosis in about one-fifth of them $(1,2)$. African and Asian countries reported elevated infection rates in comparison to Northern American as well as Northern and Western Europe (3). In Egypt, about 13.8\% of population is affected by $\mathrm{HCV}$, achieving the highest prevalence of HCV all over the world (6\%-28\%) (4-8). Hepatocellular carcinoma (HCC) is one of the most common non-dermatologic cancers in the world (9). It is the fifth most common cancer and the third most frequent cause of cancer-related death (10). The annual risk of developing HCC following cirrhosis is between $1 \%$ and $6 \%(11,12)$. The mortality from HCC is substantial with survival rates as low as $1 \%$ in two years in untreated patient $(13,14)$.

Serum $\alpha$-fetoprotein (AFP) levels are not frequently elevated in a significant proportion in patients with earlystage, potentially curable, HCC. Moreover, AFP levels may increase transiently, intermittently, or permanently in patients with viral hepatitis without HCC (15). Increase in AFP is most often paralleled by an increase in aminotransferase levels; however, the diagnostic dilemma occurs in differentiating HCC from a viral illness when an increase in AFP levels does not correlate with an increase in aminotransferase or occurs in the presence of normal levels (16). Therefore, other markers should be studied in an attempt to identify a more sensitive laboratory test.

Cytokine production is thought to play an important role in the recruitment of tumor-associated inflammatory cells, induction of angiogenesis, and direct modulation of tumor cell proliferation $(17,18)$. Inflammatory cytokines including tumor necrosis factor- $\alpha$ (TNF- $\alpha$ ) are an integral part of inflammation in chronic HCV infection. TNF- $\alpha$ mediates its effects by binding to two distinct cell surface receptors, namely, tumor necrosis factor receptor I (TNFR-I) and TNFR-II. Subsequently, proteolytic cleavage of the extracellular parts of these receptors elicits the soluble TNF receptors, i.e. sTNFR-I (-p55) and sTNFR-II $\alpha$

Copyright (C) 2014, Kowsar:; Published by Kowsar. This is an open-access article distributed under the terms of the Creative Commons Attribution-NonCommercial 4.0 International License (http://creativecommons.org/licenses/by-nc/4.0/) which permits copy and redistribute the material just in noncommercial usages, provided the original work is properly cited. 
Fouad SA et al.

(-p75). Therefore, sTNFR levels are considered sensitive and reliable indicators of the activation of TNF- $\alpha$ system, preferable to TNF- $\alpha$ itself (19).

\section{Objectives}

In this study, we investigated the value of serum level of sTNFR-II $\alpha$ in the diagnosis and early detection of HCC and its role as a potential tumor marker in patients with chronic HCV infection.

\section{Patients and Methods}

\subsection{Patients}

This study was performed in Internal Medicine Department, Faculty of Medicine, Cairo University, Cairo, Egypt, between May 2012 and December 2013. It included 110 subjects who were assigned to five groups. Group I consisted of 20 patients with chronic HCV, persistently normal transaminases for more than six months, and without liver cirrhosis. Group II included 20 patients with chronic HCV infection, elevated transaminases, and without liver cirrhosis. Group III included 20 patients with chronic HCV infection and liver cirrhosis. Group IV included 20 patients with chronic HCV infection, liver cirrhosis, and HCC diagnosed by abdominal ultrasonography, triphasic computed tomography of abdomen and serum AFP before receiving any treatment. Group V included 30 healthy individuals as a control group.

\subsubsection{Ethical Approval}

The study protocol conformed to the ethical guidelines of the 1975 Declaration of Helsinki. The ethical committee of Faculty of Medicine, Cairo University, approved this study. Written informed consents were obtained from all participants.

\subsubsection{Exclusion Criteria}

All patients with $\mathrm{HBV}$ infection or $\mathrm{HBV}-\mathrm{HCV}$ coinfection, autoimmune or drug-induced hepatitis, other autoimmune diseases, and those with renal, cardiovascular, or respiratory diseases were excluded from the study. In addition, patients with any malignancy other than HCC and pregnant women were excluded.

\subsection{Methods}

All individuals were subjected to full history taking, clinical examination, and abdominal ultrasonography. In addition, the following laboratory parameters were evaluated: liver function tests including serum levels of alanine aminotransferase (ALT), aspartate aminotransferase (AST), bilirubin, albumin (Alb), prothrombin time (PT), and prothrombin concentration, complete blood count (CBC), HBsAg ,anti-HCV Abs (by third generation ELISA), qualitative assessment of HCV-RNA in serum by nested RT-PCR assay (20), AFP by ELISA (21), and serum sTNFR-II $\alpha$.

Serum sTNFR-II $\alpha$ levels were measured by ELISA kit (DR200) using quantitative sandwich enzyme immunoassay technique (22). Kit was supplied from R \& D system Europe, Ltd. (19 Barton Lane, Abingdon Science Park, Abingdon, UK). A monoclonal antibody, specific for sTNFR-II $\alpha$, was precoated onto a microplate. Standard and study samples were pipetted into the wells and immobilized antibodies bound to any present sTNFR-II $\alpha$. After washing any unbound substances away, an enzymelinked polyclonal antibody, specific for sTNFR- II $\alpha$, was added to the wells. Following a wash to remove any unbound antibody-enzyme reagent, a substrate solution was added to the wells and color was changed in proportion to the amount of sTNFR-II $\alpha$ bound in the initial step. The color development was stopped and the intensity of the color was measured. The minimal detectable dose of sTNFR-II $\alpha$ ranged from 0.2 to $2.3 \mathrm{pg} / \mathrm{mL}$.

\subsubsection{Statistical Methodology}

The data were coded and entered into SPSS 15 (SPSS Inc., Chicago, Il, USA). The data were summarized using descriptive statistics, mean, and standard deviation. Statistical differences between groups were tested using Chi square test for qualitative variables, independentsamples t test with multiple comparisons post hoc for quantitative, normally distributed variables, and nonparametric Mann-Whitney U test and Kruskal-Wallis test for non-normally distributed quantitative variables. Twoway ANOVA test was used to compare variance of each marker levels among four different groups and the controls. P value $<0.05$ was considered as statistically significant (23).

\section{Results}

Statistical analysis of age and gender showed no significant difference among the studied groups (Table 1) The hemoglobin (Hb) level, total leucocytic count (TLC), platelet count, prothrombin concentration, and serum Alb were significantly reduced $(\mathrm{P}<0.05)$ in groups III and IV. The serum bilirubin, AST, and ALT were significantly higher in groups II, III, and IV in comparison with groups I and V. The serum AFP level was significantly elevated in groups III and IV in comparison to the other noncirrhotic groups (I and II) and the control, with the highest level in the HCC group. On the other hand, the sTNFR-II $\alpha$ level was significantly higher in HCC group (511 \pm 10.7 $\mathrm{pg} / \mathrm{mL}$ ) in comparison to the other noncirrhotic (group $\mathrm{I}, 357 \pm 6.4 \mathrm{pg} / \mathrm{mL}$; and group II $383 \pm 7.1 \mathrm{pg} / \mathrm{mL}$ ) and cirrhotic (group III, $384 \pm 1.3 \mathrm{pg} / \mathrm{mL}$ )and the control groups $(205 \pm 22.5 \mathrm{pg} / \mathrm{mL})$. There was a statistically significant difference among the non-HCC groups (I, II, and III) and the control; however, no significant difference could be detected among these groups in relation to each other (Tables 2 and 3 ; Figures 1 and 2 ). 
Fouad SA et al.

Our results revealed no significant correlation between the level of TNFR-II $\alpha$ and demographic and laboratory parameters within the different groups, except in group II that we found a significant correlation between TNFR-II $\alpha$ and either AST $(r=0.45$; and $\mathrm{P}<0.05)$ or ALT $(r=0.25$; and
$\mathrm{P}<0.05)$

The sTNF-II $\alpha$ is considered a better positive marker than being a negative one in diagnosing HCC with higher sensitivity (99\%) and accuracy (87\%) at a cutoff value of $\geq 250$ pg/mL (Table 4).

Table 1. Demographic Data of Different Groups

\begin{tabular}{lcccc}
\hline Variable & Group I $(\mathbf{N}=\mathbf{2 0})$ & Group II $(\mathbf{N}=\mathbf{2 0})$ & Group III $(\mathbf{N}=\mathbf{2 0})$ & Group IV $(\mathbf{N}=\mathbf{2 0})$ \\
\hline Age $^{\mathrm{a}}$ & $53.7 \pm 4$ & $45 \pm 4.6$ & $54.5 \pm 3$ & $46 \pm 4.8$ \\
Sex & & & & \\
Male & $9(90)$ & $9(90)$ & $8(80)$ & $8(80)$ \\
Female & $1(10)$ & $1(10)$ & $2(20)$ & $2(20)$ \\
\hline
\end{tabular}

${ }^{\mathrm{a}}$ Values are expressed as mean $\pm \mathrm{SE}$ or No. (\%).

Table 2. Laboratory Data of Different Groups a,b

\begin{tabular}{|c|c|c|c|c|c|}
\hline Variable & Group I (No. 20) & Group II (No. 20) & Group III (No. 20) & Group IV(No. 20) & Controls (No. 30) \\
\hline HB, gm/dL & $12 \pm 1.1$ & $11.9 \pm 1.3$ & $9.6 \pm 0.9$ & $9.3 \pm 1$ & $13.9 \pm 0.8$ \\
\hline TLC & $5 \pm 0.9$ & $4 \pm 1.6$ & $3.7 \pm 2.7$ & $3.6 \pm 0.6$ & $4.7 \pm 0.7$ \\
\hline Platelets & $365 \pm 7.1$ & $162 \pm 5.8$ & $128 \pm 3.5$ & $119 \pm 7.3$ & $380 \pm 6.2$ \\
\hline PC,\% & $91 \pm 5.6$ & $85 \pm 7.8$ & $39.5 \pm 6$ & $33.8 \pm 4.3$ & $99.5 \pm 0.8$ \\
\hline Albumin, gm/dL & $4 \pm 0.6$ & $3.6 \pm 0.7$ & $2.6 \pm 0.6$ & $2.08 \pm 0.6$ & $5 \pm 0.7$ \\
\hline $\begin{array}{l}\text { Total bilirubin, } \\
\text { mg/dL }\end{array}$ & $0.69 \pm 0.9$ & $1.1 \pm 0.9$ & $3.4 \pm 1.3$ & $4.1 \pm 2.14$ & $0.48 \pm 0.20$ \\
\hline AST, mg/dL & $32 \pm 3$ & $62 \pm 1.6$ & $45 \pm 1.3$ & $50 \pm 9.5$ & $26.2 \pm 6$ \\
\hline ALT, mg/dL & $34 \pm 4$ & $74 \pm 1.4$ & $41 \pm 1.2$ & $43 \pm 4.7$ & $28 \pm 6.6$ \\
\hline AFP, $\mathbf{n g} / \mathbf{m L}$ & $5.6 \pm 4$ & $7.3 \pm 4$ & $13 \pm 4.7$ & $1882 \pm 330$ & $3.8 \pm 0.8$ \\
\hline sTNFR-II $\alpha$, pg/mL & $357 \pm 6.4$ & $383 \pm 7.1$ & $384 \pm 1.3$ & $511 \pm 10.7$ & $205 \pm 22.5$ \\
\hline
\end{tabular}

a Values are expressed as mean $\pm S E$

${ }^{b}$ Means followed by the same superscript letter within the same row means insignificant variation $(\mathrm{P}>0.05)$.

Table 3. Mean Values of Soluble Tumor Necrosis Factor Receptor-II $\alpha$ in Non-hepatocellular Carcinoma and Control Groups a,b

\begin{tabular}{lccc}
\hline Variable & Non-HCC $(\mathbf{N}=\mathbf{6 0})$ & HCC Group $(\mathbf{N}=\mathbf{2 0})$ & Controls $(\mathbf{N}=\mathbf{3 0})$ \\
\hline Mean \pm SD & $342 \pm 11.4$ & $511 \pm 10.7$ & $205 \pm 22.5$ \\
\hline
\end{tabular}

a Values are expressed as mean \pm SE. Statistically significant level is defined as $\mathrm{P}<0.05$.

$\mathrm{b}$ Means followed by the same superscript letter within the same row means non-significant variation $(\mathrm{P}>0.05)$.

Table 4. Validity of Soluble Tumor Necrosis Factor ReceptorIIain Diagnosis of Hepatocellular Carcinoma

\begin{tabular}{lc}
\hline Variable & No. $(\%)$ \\
\hline Best cutoff $=\mathbf{2 5 0}, \mathbf{p g} / \mathbf{M l}$ & \\
AUC $^{\text {a }}$ & 0.93 \\
Sensitivity & 99 \\
Specificity & 72 \\
PPV & 78 \\
NPV & 95 \\
Accuracy & 87 \\
\hline a Abbreviations: AUC, area under the curve; PPV, positive predictive \\
value; and NVP, negative predictive value.
\end{tabular}

\section{Discussion}

Chronic liver disease (CLD) is characterized by raised cytokines level that might represent a sequel of liver dysfunction as well as an inflammatory process (24). Cytokines-induced discrepancy between T helper 1 (Th1) and $\mathrm{T}$ helper 2 (Th2) can extend inflammation, leading to necrosis, fibrosis, and CLD with consequent possible progression and evolution of HCC (24-26).

Such elevated serum cytokines could be used as biomarkers for early diagnosis of HCC in patients with HCVrelated CLD. In addition, they were previously investigated for possible use as predictors for treatment response to interferon (IFN) in patients with HCV genotype-4 infection. Numerous cytokines including soluble Fas (sFas), sTNFR-II $\alpha$, interleukin-2 receptor (IL-2R), and interleu 


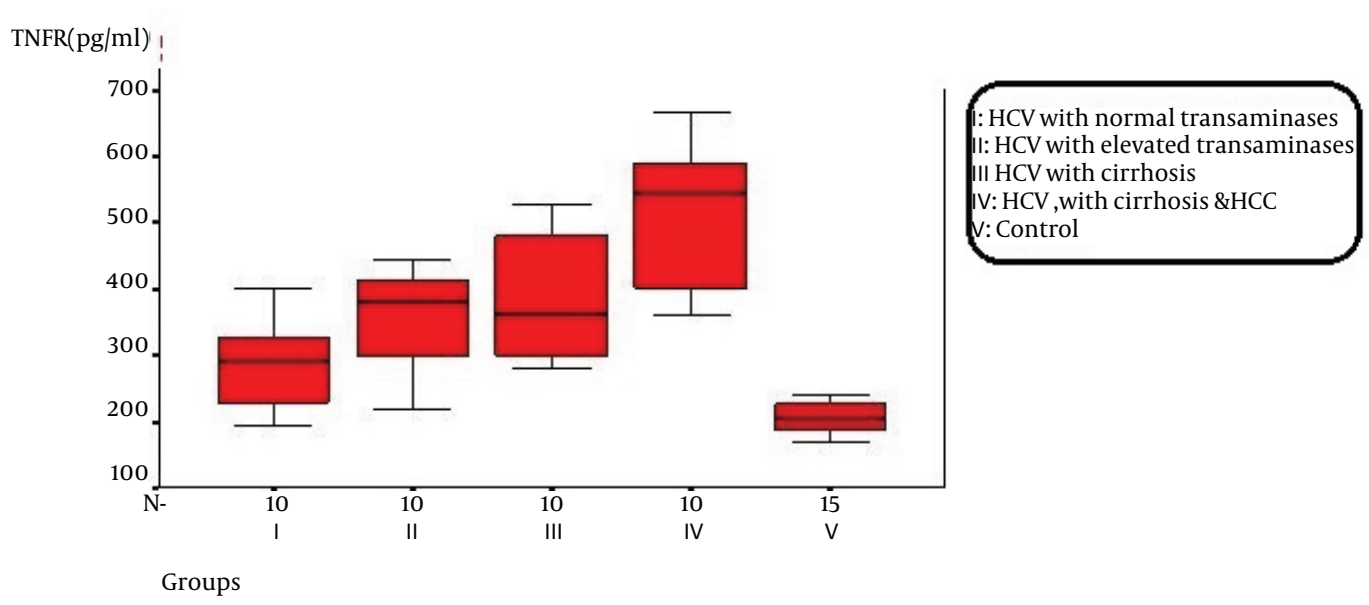

Figure 1. Levels of Soluble Tumor Necrosis Factor Receptor-II $\alpha$ in Different Groups

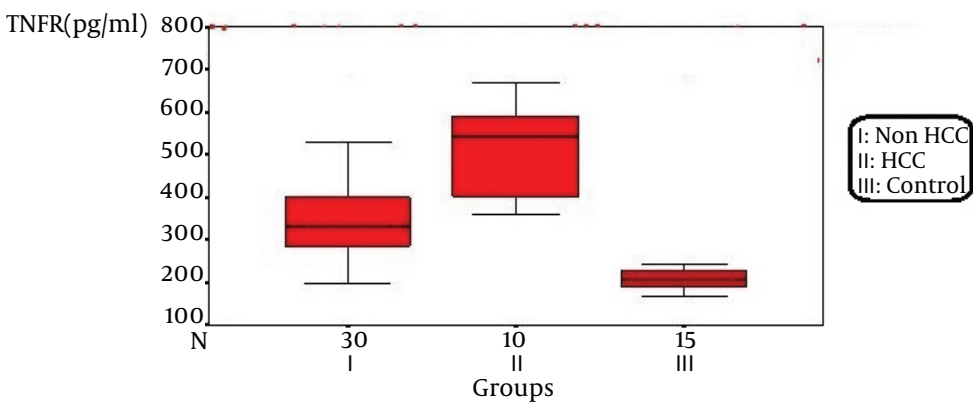

Figure 2. Levels of Soluble Tumor Necrosis Factor Receptor-II $\alpha$ in Hepatocellular Carcinoma, Non-hepatocellular Carcinoma, and Control Groups

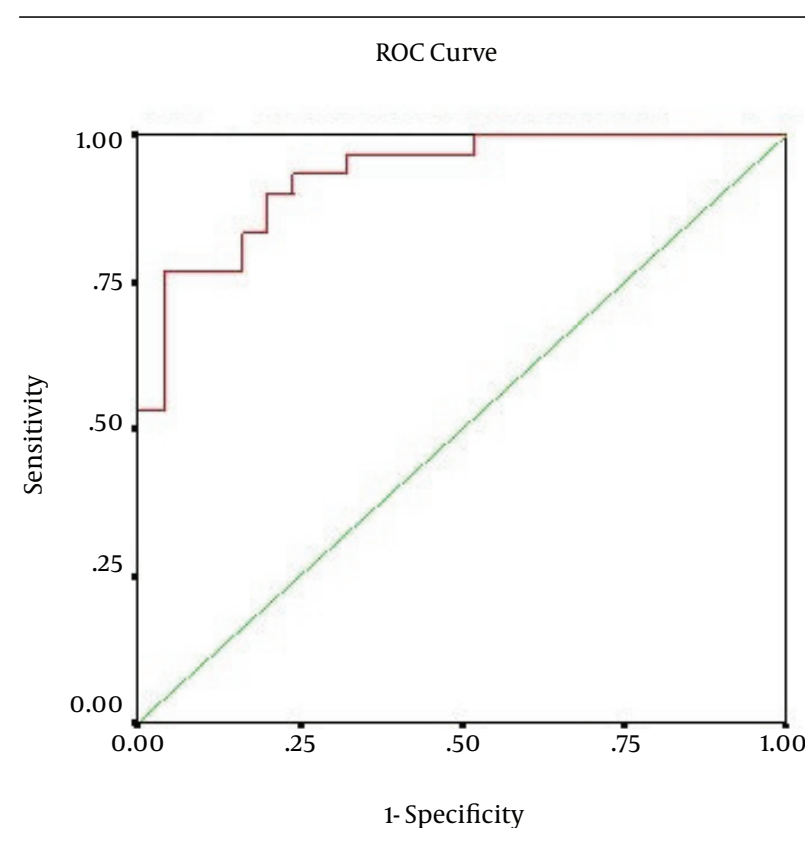

Figure 3. ReceptorOperativeCurve of Serum Level of Soluble Tumor Necrosis Factor Receptor-II $\alpha$ in Early Detection of Hepatocellular Carcinoma kin-8 (IL-8) are involved in HCC invasion and metastasis $(27,28)$.

Additionally, a recent report showed over-expression of $\mathrm{CD} 5 \mathrm{~L}$ in HCV-HCC in comparison to HCV-cirrhosis. CD5L is a secreted glycoprotein belonging to the scavenger receptor cysteine-rich superfamily. Although biomarker studies on liver tissues could be a useful strategy for determining new pathogenic biomarkers for diagnostic and/or prognostic processes, serum has much main concern for finding reasonably priced, appropriate, and noninvasive biomarkers (29).

Nonetheless, there are contradictory reports on these markers as predictors for HCC; it was found that IL-2R was not detectable in patients with HCC in comparison to patients with chronic hepatitis and liver cirrhosis (30). Moreover, a previous study revealed that, levels of IL-8 were significantly lower in patients with HCC than in the other groups (31) while contradictory studies found that serum IL-8 levels were markedly elevated in most patients with HCC in comparison to healthy subjects (32) and were overexpressed in the HCC cells in comparison with the non-affected liver cells (33). Consequently, due to the large multitude of reported CLD-associated biomarkers, selecting the most useful biomarkers in clinical practice has been more a challenging. Notably, sTNFR-IIo 
Fouad SA et al.

was closely correlated with disease progression in chronic HCV infection. Moreover, TNFRs up-regulation might alter host response and potentially add to liver damage (34).

Thus, in the current study we determined the value of serum level of sTNFR-II $\alpha$ in the diagnosis and early detection of HCC in patients with chronic HCV infection. Our results revealed that there was no statistically significant difference regarding age between patients with HCC and other studied groups, which disagreed with Zekri et al. who stated significantly higher mean of patients' age with HCC than that of the other groups (31). This might be related to under diagnosis of early stage cirrhosis, which had started at younger age, possibly due to low rates of biopsy. This was in concert with results of a previous cohort (35) that reported a significant increase in the prevalence of cirrhosis and HCC in patients with HCV infection over the past ten years. The authors added that after adjustment for sex and increasing age of the HCV cohort, the upward slopes in the prevalence of cirrhosis and HCC were lower than the corresponding slopes in the crude rates. They concluded that aging of the patients with HCV infection explains a significant proportion of the rising trend in the prevalence of cirrhosis and HCC (20\% and $47 \%$, respectively) with time. Another explanation is that patients with HCV acquired their infection earlier and thus, would have had their infection for a longer time with age progression. If it was true, it would mean that the HCC prevails. Lastly, records from previous studies are liable to be misjudged; the data from recalibrated mathematical models suggest that the age prevalence prevalence of HCV and cirrhosis might be definitely higher than was previously reported (36).

In addition, we found that the serum $\mathrm{Hb}$ level was significantly lower in patients with liver cirrhosis (group III) and HCC (group IV) than the other groups. This difference could be explained by acute and chronic gastrointestinal blood loss, folate deficiency, hypersplenism, bone marrow suppression, and the anemia of chronic disease. This is in agreement with Sakisaka et al. who stated that although raised serum erythropoietin (EPO) levels might be present in up to $23 \%$ of patients with HCC, elevations in $\mathrm{Hb}$ concentration or packed cell volume are uncommon and most patients are anemic at diagnosis because of other side effects of the tumor (37).

In the present study, the total leucocytic and platelet counts were significantly reduced in patients with cirrhosis and those with HCC in comparison with the other groups .This finding was in agreement with the results by Pratt and Kaplan, explaining that observed leucopenia with liver cirrhosis might be due to hypersplenism with splenic margination while thrombocytopenia might be mainly caused by portal hypertension with attendant congestive splenomegaly. An enlarged spleen can result in temporary sequestration of up to $90 \%$ of the circulating platelet mass. Decreased thrombopoietin levels might also contribute to thrombocytopenia (38).
Our study revealed that the serum Alb and prothrombin concentration were significantly lower in patients with cirrhosis and those with HCC in comparison with the other groups, which could be explained by decreased synthesis of Alb and coagulation factors by the diseased liver. It was in agreement with the report by Tripod et al. showing poor utilization of vitamin $\mathrm{k}$ in advanced parenchymal liver disease (39).

The present study revealed that the serum transaminases were significantly elevated in patients with HCC in comparison to those with persistently normal ALT levels and the controls but with insignificant difference with the cirrhotic group. In agreement with our results, Zekri et al. and Sugiyama et al. stated that liver function tests values were significantly elevated in patients with HCC when compared to those with CLD $(31,40)$. Moreover, Young et al. reported that patients with HCC had the highest values for various concurrently measured liver function tests, AST/ALT, ALT, and AST than patients with cirrhosis did (41).

Although authors (31) confirmed that serum TNFR-II and AFP might be used as combined markers in patients with HCV infection who are at high risk of developing HCC, additional studies are mandatory to reevaluate these findings before their application at the population level. Our study revealed extraordinary high amounts of AFP values $(\mathrm{P}<0.05)$ in patients with HCC in comparison to other groups. Moreover, sTNFR-II $\alpha$ values were significantly increased in the same group of patients (HCC) in comparison to other groups. High serum levels of AFP in the current study could be explained by the presence of other factors that might affect AFP and sTNFR-II $\alpha$ levels in serum as high levels of serum AFP have been accompanied with larger tumor size, bilobar association, immense or diffuse-type tumors, and portal vein thrombosis(42). These factors need further elucidation in more detailed studies. On the other side, low sTNFR-II level in comparison to AFP in the current study might be related to the histologic pattern of the disease. Such hypothesis could be ascertained by the previous published results stating that enhanced TNFRs in chronic HCV infection might reflect the histologic activity of the disease (34).

Our results showed no statistically significant correlation between sTNFR-II $\alpha$ and different laboratory variables among different groups, except in group II where there was a statistically significant positive correlation between the levels of sTNFR-II $\alpha$ and AST and ALT $(\mathrm{P}<0.05)$. In agreement with our results, Itoh et al. reported positive correlations between sTNFR-II $\alpha$ and several liver disease markers (ALT, AST, and gammaglutamyl transferase) as well as with Knodell's histologic activity index score in subjects with chronic HCV infection (43).

We reported that levels of sTNFR-II $\alpha$ were significantly elevated in patients with chronic HCV infection in comparison to the control subjects $(\mathrm{P}<0.05)$. Similar results were reported by Zekri et al., who stated that levels of sTNFR-II $\alpha$ were elevated in patients with PNALT, CLD, and 
HCC (31). Moreover, Kato et al. mentioned that sTNFRII $\alpha$ was closely correlated with disease progression in chronic HCV infection (12). On the same line, Kallinowski et al. (34), Aderka et al. (44), and Robert et al. (45) stated that HCC cases experience an elevated type 1 immune response before the development of HCC and that levels of sTNFR-II $\alpha$ and soluble intracellular adhesion molecule 1 (sICAM-1) were positively correlated with each other. On the other hand, Kakumu et al. reported that the serum level of sTNFR- II $\alpha$ was highest in both HCC and CLD groups (46).

The rate of progression to end-stage liver disease might be related to an up-regulation of the TNF $\alpha /$ Fas pathways and an age-dependent host response (47). Activities of TNF $\alpha$ are mediated through sTNFR-I and II. Released proinflammatory TNF $\alpha$ by host and tumor cells is an important factor in initiation, proliferation, angiogenesis, and metastasis of various cancer types $(48,49)$.

Regarding the mean levels of serum sTNFR-II $\alpha$ in the present study, a significant difference was shown between the HCC and the non-HCC groups. The best cutoff value for diagnosing HCC was $\geq 250 \mathrm{pg} / \mathrm{mL}$ with sensitivity of $99 \%$, specificity of $72 \%$, positive predictive value of $78 \%$, and negative predictive value of $95 \%$ with $87 \%$ accuracy. However, a higher cutoff value was reported by Zekri et al. who stated that levels of sTNFR-II $\alpha$ were significantly elevated in patients with HCC in comparison to those with PNALT and CLD. Analysis of sTNFR-II $\alpha$ by receptive operative curves revealed satisfactory values regarding sensitivity (70.6\%) and specificity (90\%) at a cutoff value of $\geq 398 \mathrm{pg} / \mathrm{mL}$ (31).

In conclusion, although serum AFP level is still considered as the key serum marker for HCC diagnosis, it could be elevated in some noncancerous liver insults and could be at a low level in some patients with $\operatorname{HCC}(50,51)$. Consequently, the present study elucidates the prospective role of sTNFR-II $\alpha$ as a potential marker of HCC. We revealed that the serum level of sTNFR-II $\alpha$ was significantly higher in patients with HCC in comparison to the other groups. The sTNFR-II $\alpha$ at a cut off value $\geq 250 \mathrm{pg} / \mathrm{mL}$ is highly suggestive of HCC in patients with chronic HCV infection and liver cirrhosis. However, auxiliary studies, involving larger scales of patients at various stages of CLD and HCC, in addition to complementary assessment of the effect of HCC treatment on the serum level of sTNFR-II $\alpha$ are mandatory.

\section{Acknowledgements}

The authors thank the support of the Internal Medicine Department ,Faculty of Medicine, Cairo university.

\section{Authors' Contributions}

Shawky A. Fouad: development of the original idea and the protocols, study concept and design, data analyzing, and critical revision of the manuscript; Nehal H. El Saaid: protocol development and manuscript revision; Nagwa
A. Mohamed: performing laboratory work of the study; and Osama M. Abutaleb: collecting the scientific material and contribution to writing the manuscript.

\section{References}

1. Di Bisceglie AM. Hepatitis C. Lancet. 1998;351(9099):351-5

2. Flamm SL. Chronic hepatitis $\mathrm{C}$ virus infection. JAMA. 2003;289(18):2413-7.

3. Shepard CW, Finelli L, Alter MJ. Global epidemiology of hepatitis C virus infection. Lancet Infect Dis. 2005;5(9):558-67.

4. Frank C, Mohamed MK, Strickland GT, Lavanchy D, Arthur $\mathrm{RR}$, Magder LS, et al. The role of parenteral antischistosomal therapy in the spread of hepatitis $C$ virus in Egypt. Lancet. 2000;355(9207):887-91.

5. Nafeh MA, Medhat A, Shehata M, Mikhail NN, Swifee Y, Abdel-Hamid M, et al. Hepatitis $C$ in a community in Upper Egypt: I. Crosssectional survey. Am J Trop Med Hyg. 2000;63(5-6):236-41.

6. Abdel-Aziz F, Habib M, Mohamed MK, Abdel-Hamid M, Gamil F, Madkour S, et al. Hepatitis C virus (HCV) infection in a community in the Nile Delta: population description and HCV prevalence. Hepatology. 2000;32(1):111-5.

7. el-Sadawy M, Ragab H, el-Toukhy H, el-Mor Ael L, Mangoud AM, Eissa $\mathrm{MH}$, et al. Hepatitis $\mathrm{C}$ virus infection at Sharkia Governorate, Egypt: seroprevalence and associated risk factors.J Egypt Soc Parasitol. 2004;34(1 Suppl):367-84.

8. Deuffic-Burban S, Mohamed MK, Larouze B, Carrat F, Valleron AJ Expected increase in hepatitis C-related mortality in Egypt due to pre-2000 infections. J Hepatol. 2006;44(3):455-61.

9. Bruix J. Treatment of hepatocellular carcinoma. Hepatology. 1997;25(2):259-62.

10. Villeneuve JP, Desrochers M, Infante-Rivard C, Willems B, Raymond G, Bourcier M, et al. A long-term follow-up study of asymptomatic hepatitis B surface antigen-positive carriers in Montreal. Gastroenterology. 1994;106(4):1000-5.

11. Sherman M, Peltekian KM, Lee C. Screening for hepatocellular carcinoma in chronic carriers of hepatitis B virus: incidence and prevalence of hepatocellular carcinoma in a North American urban population. Hepatology. 1995;22(2):432-8.

12. Kato Y, Nakata K, Omagari K, Furukawa R, Kusumoto Y, Mori I, et al. Risk of hepatocellular carcinoma in patients with cirrhosis in Japan. Analysis of infectious hepatitis viruses. Cancer. 1994;74(8):2234-8.

13. Okuda K, Ohtsuki T, Obata H, Tomimatsu M, Okazaki N, Hasegawa $\mathrm{H}$, et al. Natural history of hepatocellular carcinoma and prognosis in relation to treatment. Study of 850 patients. Cancer. 1985;56(4):918-28.

14. Calvet X, Bruix J, Gines P, Bru C, Sole M, Vilana R, et al. Prognostic factors of hepatocellular carcinoma in the west: a multivariate analysis in 206 patients. Hepatology.1990;12(4 Pt1):753-60.

15. Gebo KA, Chander G, Jenckes MW, Ghanem KG, Herlong HF, Torbenson MS, et al. Screening tests for hepatocellular carcinoma in patients with chronic hepatitis C: a systematic review. Hepatology. 2002;36(5 Suppl 1):S84-92.

16. Collier J, Sherman M. Screening for hepatocellular carcinoma. Hepatology. 1998;27(1):273-8.

17. Aref S, Menessy A. Correlation of soluble IL-2R and tumor necrosis factor $\alpha$ receptor (TNF- $\alpha$ R) levels with severity of chronic hepatitis C liver injury. Egypt J Hematol. 1997;22:327-40.

18. Quentmeier H, Dirks WG, Fleckenstein D, Zaborski M, Drexler HG. Tumor necrosis factor-alpha-induced proliferation requires synthesis of granulocyte-macrophage colony-stimulating factor. Exp Hematol. 200 0;28(9):1008-15.

19. Beutler B, van Huffel C. Unraveling function in the TNF ligand and receptor families. Science. 1994;264(5159):667-8.

20. Berg T, Muller AR, Platz KP, Hohne M, Bechstein WO, Hopf U, et al Dynamics of GB virus $C$ viremia early after orthotopic liver transplantation indicates extrahepatic tissues as the predominant site of GB virus C replication. Hepatology. 1999;29(1):245-9.

21. Cole LA. New discoveries on the biology and detection of human chorionic gonadotropin. Reprod Biol Endocrinol. 2009;7:8.

22. Heemann C, Kreuz M, Stoller I, Schoof N, von Bonin F, Ziepert M, 
Fouad SA et al.

et al. Circulating levels of TNF receptor II are prognostic for patients with peripheral T-cell non-Hodgkin lymphoma. Clin Cancer Res. 2012;18(13):3637-47.

23. Knapp RG, Miller C, Clinton M. Clinical epidemiology and biostatistics. 3 edMaryland: Williams \& Wilkins; 1992

24. Tilg H, Wilmer A, Vogel W, Herold M, Nolchen B, Judmaier G, et al Serum levels of cytokines in chronic liver diseases. Gastroenterology. 1992;103(1):264-74.

25. Jacobson Brown PM, Neuman MG. Immunopathogenesis of hepatitis $C$ viral infection: Th1/Th2 responses and the role of cytokines. Clin Biochem. 2001;34(3):167-71.

26. Budhu A, Wang XW. The role of cytokines in hepatocellular carcinoma. JLeukoc Biol. 2006;80(6):1197-213.

27. Zekri AR, El-Din HM, Bahnassy AA, El-Shehabi AM, El-Leethy H, Omar A, et al. TRUGENE sequencing versus INNO-LiPA for subgenotyping of HCV genotype-4. J Med Virol. 2005;75(3):412-20.

28. Beutler B. TNF, immunity and inflammatory disease: lessons of the past decade. J Investig Med.1995;43(3):227-35.

29. Sarvari J, Mojtahedi Z, Taghavi SA, Kuramitsu Y, Shamsi Shahrabadi M, Ghaderi A, et al. Differentially Expressed Proteins in Chronic Active Hepatitis, Cirrhosis, and HCC Related to HCV Infection in Comparison With HBV Infection: A proteomics study. Hepat Mon. 2013;13(7)

30. Morshed SA, Fukuma H, Kimura Y, Watanabe S, Nishioka M. Interferon-gamma, interleukin (IL)-2 and IL-2 receptor expressions in hepatitis C virus-infected liver. Gastroenterol Jpn. 1993;28 Suppl 5:59-66.

31. Zekri AR, Alam El-Din HM, Bahnassy AA, Zayed NA, Mohamed WS, El-Masry SH, et al. Serum levels of soluble Fas, soluble tumor necrosis factor-receptor II, interleukin-2 receptor and interleukin-8 as early predictors of hepatocellular carcinoma in Egyptian patients with hepatitis $\mathrm{C}$ virus genotype-4. Comp Hepatol. 2010;9(1):1.

32. Ren Y, Poon RT, Tsui HT, Chen WH, Li Z, Lau C, et al. Interleukin-8 serum levels in patients with hepatocellular carcinoma: correlations with clinicopathological features and prognosis. Clin Cancer Res. 2003;9(16 Pt 1):5996-6001.

33. Akiba J, Yano H, Ogasawara S, Higaki K, Kojiro M. Expression and function of interleukin-8 in human hepatocellular carcinoma. Int J Oncol. 2001;18(2):257-64.

34. Kallinowski B, Haseroth K, Marinos G, Hanck C, Stremmel W, Theilmann L, et al. Induction of tumour necrosis factor (TNF) receptor type p55 and p75 in patients with chronic hepatitis C virus (HCV) infection. Clin Exp Immunol. 1998;111(2):269-77.

35. Kanwal F, Hoang T, Kramer JR, Asch SM, Goetz MB, Zeringue A et al. Increasing prevalence of HCC and cirrhosis in patients with chronic hepatitis C virus infection. Gastroenterology. 2011:140(4):1182-1188 e1.

36. Davis GL, Alter MJ, El-Serag H, Poynard T, Jennings LW. Aging of hepatitis $\mathrm{C}$ virus (HCV)-infected persons in the United States: a multiple cohort model of HCV prevalence and disease progression. Gastroenterology. 2010;138(2):513-21.

37. Sakisaka S, Watanabe M, Tateishi H, Harada M, Shakado S, Mimura Y, et al. Erythropoietin production in hepatocellular carcinoma cells associated with polycythemia: immunohistochemical evidence. Hepatology.1993;18(6):1357-62.
38. Pratt D, Kaplan M. Evaluation of the Liver A: Laboratory Tests. In: Schiff ER, Sorrell MF, Maddrey WC editors. Schiff's Diseases of the Liver.. Philadelphia: Lippincott Williams Wilkens; 2011. p. 205.

39. Tripodi A, Salerno F, Chantarangkul V, Clerici M, Cazzaniga M, Primignani $\mathrm{M}$, et al. Evidence of normal thrombin generation in cirrhosis despite abnormal conventional coagulation tests. Hepatology. 2005;41(3):553-8.

40. Sugiyama M, Kanno T, Ohkubo A, Muto Y, Murata K, Ueno Y. [The clinical usefulness of the molar ratio of branched-chain amino acids to tyrosine (BTR) in discriminating stage of chronic liver diseases]. Rinsho Byori.1992;40(6):673-8.

41. Young KC, Lin PW, Hsiao WC, Chang TT, Chang YC, Wu HL. Variation of hepatitis $\mathrm{C}$ virus load, hypervariable region 1 quasispecies and CD81 hepatocyte expression in hepatocellular carcinoma and adjacent non-cancerous liver. J Med Virol. 2002;68(2):188-96.

42. Tangkijvanich P, Anukulkarnkusol N, Suwangool P, Lertmaharit S, Hanvivatvong O, Kullavanijaya P, et al. Clinical characteristics and prognosis of hepatocellular carcinoma: analysis based on serum alpha-fetoprotein levels. J Clin Gastroenterol. 2000;31(4):302-8.

43. Itoh Y, Okanoue T, Ohnishi N, Sakamoto M, Nishioji K, Nakagawa $\mathrm{Y}$, et al. Serum levels of soluble tumor necrosis factor receptors and effects of interferon therapy in patients with chronic hepatitis C virus infection. Am J Gastroenterol.1999;94(5):1332-40.

44. Aderka D, Wysenbeek A, Engelmann H, Cope AP, Brennan F, Molad Y, et al. Correlation between serum levels of soluble tumor necrosis factor receptor and disease activity in systemic lupus erythematosus. Arthritis Rheum.1993;36(8):1111-20.

45. Suruki RY, Mueller N, Hayashi K, Harn D, DeGruttola V, Raker CA, et al. Host immune status and incidence of hepatocellular carcinoma among subjects infected with hepatitis $C$ virus: a nested case-control study in Japan. Cancer Epidemiol Biomarkers Prev. 2006;15(12):2521-5.

46. Kakumu S, Okumura A, Ishikawa T, Yano M, Enomoto A, Nishimura $\mathrm{H}$, et al. Serum levels of IL-10, IL-15 and soluble tumour necrosis factor-alpha (TNF-alpha) receptors in type $\mathrm{C}$ chronic liver disease. Clin Exp Immunol. 1997;109(3):458-63.

47. Macias J, Sanchez-Quijano A, Pineda JA, Abad MA, Rubio A, Rosa R, et al. Minimal liver injury in chronic hepatitis $C$ virus infection is associated with low levels of soluble TNF-alpha/Fas receptors and acquisition in childhood. Liver. 2001;21(6):410-4

48. Luo JL, Maeda S, Hsu LC, Yagita H, Karin M. Inhibition of NFkappaB in cancer cells converts inflammation- induced tumor growth mediated by TNFalpha to TRAIL-mediated tumor regression. Cancer Cell. 2004;6(3):297-305.

49. Herbein G, O'Brien WA. Tumor necrosis factor (TNF)-alpha and TNF receptors in viral pathogenesis. Proc Soc Exp Biol Med. 2000;223(3):241-57.

50. Tateishi R, Yoshida H, Matsuyama Y, Mine N, Kondo Y, Omata M. Diagnostic accuracy of tumor markers for hepatocellular carcinoma: a systematic review. Hepatol Int. 2008;2(1):17-30.

51. Snowberger N, Chinnakotla S, Lepe RM, Peattie J, Goldstein R Klintmalm GB, et al. Alpha fetoprotein, ultrasound, computerized tomography and magnetic resonance imaging for detection of hepatocellular carcinoma in patients with advanced cirrhosis. Aliment Pharmacol Ther. 2007;26(9):1187-94. 